\title{
Study on Necrotrophic Characteristic of Colletotrichum capsici on Cowpea Seedlings
}

\author{
C. Maya ${ }^{1}$, Nabamita Seal ${ }^{2}$ \\ ${ }^{1,2}$ Department of Botany, Bangalore University, Bangalore-560056, Karnataka, India
}

\begin{abstract}
Colletotrichum spp. which causes anthracnose diseases in plants is a hemibiotrophs termed by Luttrell (1974), which uses both biotrophic and necrotrophic modes of nutrition at different stages of their development. Literature observes that, after an initial biotrophic phase of varying duration, these fungi switch to necrotrophy which leads to death of the affected tissues (which causes water soaked lesions and holes) and severe infection results in death of the entire plant body. It is observed from the literature that, causal agent of chilli anthracnose $C$. capsici, nectrotrophic behaviour is less reviewed for its interaction with other plants. This paper, studies to understand the establishment of pathogenecity of C. capsici on the host plant, cowpea. This success leads to necrotrophic characteristic of the fungi $C$. capsici. The study observed that, after an inoculation of conidial suspension artificially in lab on seedlings of cowpea other than its specific host chilli with sprayer, susceptible tissues started rotting with growth of acervuli present over the entire surface of the hypocotyls. Pahogenecity involves by initial infections by massive production of appressoria containing spores all over the hypocotyl surface. Subsequently, hyphae grew inside the host tissues and destroyed the walls of underlying cortical cells. This was associated with extensive death of adjacent cells, which led to production of water-soaked lesions and finally it led to death of entire seedlings on severe infection (nectrotrophy).
\end{abstract}

Keywords: Hemibiotrophy, Necrotrophy, anthracnose, Colletotrichum capsici, cowpea seedling

\section{Introduction}

The Deuteromycetous fungus Colletotrichum has wide range of host susceptibility ranging from gymnosperms, angiosperms, ornamental and fruit plants, vegetables, crops or even grassses. It has a primarily tropical and subtropical distribution, although there are some species affect temperate crops too. The genus was recently voted the eighth most important group of plant pathogenic fungi in the world, based on perceived scientific and economic importance (Dean et al. 2012). The lifestyle of Colletotrichum species is called hemibiotrophic, as it is both biotrophic and necrotrophic, based on obtaining their nutrients from living cells (biotrophs) and those obtaining nutrients from host cells that they have killed (necrotrophs). However, there is a large group of fungi, termed hemibiotrophs by Luttrell, which use both modes of nutrition at different stages of their development. After an initial biotrophic phase of varying duration, these fungi switch to necrotrophy. Such nutritional shifts are common among ascomycete and deuteromycete fungi that cause necrotic spotting on leaves, stems and fruits and the developmental stages are sequentially established. The infection process is described below.

Initiation of infection in a host cell: Species of Colletotrichum possess very interesting and diverse strategies for invading host tissue, ranging from intra cellular hemibiotrophy to subcuticular intramural necrotrophy (Steffen Münch, 2007). In addition, these pathogens develop a series of specific infection structures, including germtube, appressoria, intracellular hyphae and secondary necrotrophic hyphae (Ajay Kumar Gautam, 2013). After penetration, an infection vesicle and primary hyphae are formed. These structures do not kill the host cell and show some similarities with haustoria formed by powdery mildews and rust fungi. Therefore, this stage of infection is called biotrophic. Later in the infection process, necrotrophic secondary hyphae spread within and kill the host tissue.

Establishment and maintenance of biotrophy: Münch et al. (2008) in their studies shown that immediately after recognition of the host, a short germ tube is formed from germinating conidia of Colletotrichum while invation of the host epidermal cells differentiate a highly specialized infection cell called an appressorium. As the appressorium matures, a melanin layer is included into the appressorial cell wall and osmotically active compounds are synthesized to high concentrations (Mendgen and Deising,1993; Deising et al., 2000; Kubo et al., 2000). Melanization is thought to result in selective permeability of the cell wall (Howard et al.,1991), which, in combination with the osmolytes in the appressorium which leads to generation of enormous turgor pressure.

In this study chilli anthracnose pathogen $C$. capsici has been selected for the experiment to infect cowpea seedlings and to study its effect on the plant other than its specific host chilli. Chilli anthracnose disease caused by $C$. capsici can occur on leaves, stems, and both pre- and post-harvest fruits (Isaac, 1992). Typical fruit symptoms are circular or angular sunken lesions, with concentric rings of acervuli that are often wet and produce pink to orange conidial masses (Than et al, 2008).

\section{Literature Survey}

Thines et al. (2006) showed in their studies that, during necrotrophic development, the pathogen may not primarily rely on prevention of defense initiation but rather actively kill the host tissue, e.g. by secretion of toxins. Several secondary metabolites of Colletotrichum species have been identified, but only a few of them possess phytotoxic activity. For example, terpenoid compounds called colletotrichins function as non-host-specific phytotoxins of the tobacco pathogen Colletotrichum nicotina. When 


\section{International Journal of Science and Research (IJSR) \\ ISSN (Online): 2319-7064}

Index Copernicus Value (2013): 6.14 | Impact Factor (2014): 5.611

colletotrichins were applied to tobacco leaves, they ind ıced symptoms similar to those of tobacco anthracnose cause $I$ by C. nicotina. It causes rapid loss of membrane intę̧ rity. Ultrastructural analyses revealed that the plasmalemma was damaged and in addition, colletotrichins have been repr rted to bind to the oxidized form of cytochrome, the eby inhibiting electron flow in the mitochondrial respirition chain.

Kim et al. (2004) suggested that necrotrophy occurs pos ibly due to epidermal cytoplasm became condensed and s nall vacuoles increased and cell destruction extended to the subepidermal cells of the plant, which are likely to be damaged by the pathogen enzymes. At later stage; of infection, tissues were colonized inter- and intracellularl $r$ by the pathogen. This structural feature indicated that the infection was governed by necrotrophic fungal growth.

Pring et al, 1995, experimented on the pathogenicity, host range and infection process of three isolates of Colletotrichum capsici, from cowpea (Vigna unguiculata), bean (Phaseolus vulgaris) and betle vine (Piper betle). The study showcased, successful pathogenesis is based on suppression of host defence responses through rapid killing of infected tissues.

The objective of this study is to detect the ability of infection of Colletotrichum capsici to the plant cowpea other than its specific host plant Capsicum sp. when inoculated in lab and its effect in this artificial inoculation process. The study also aimed at understanding less reviewed nectrotrophic behaviour of Colletotrichum capsici in cowpea seedlings.

\section{Methodology}

For conducting this experiment materials used and methods followed have been described below:

Isolation of pathogen from tissue. The fungus has been isolated from diseased plant specimen (chilli). Chilli (Capsicum annuum) were cut into small bits then were rinsed in $0.5 \% \mathrm{NaOCl}$ for 1 minute and then washed thoroughly 2-3 times in sterile distilled water.

Production of inoculum: Chilli bits were placed in 5 sets of petridishes containing PDA media $(5 \mathrm{~mm})$ and kept under aseptic condition. Inoculated plates were incubated at $27^{\circ}{ }_{ \pm}$ $1^{0} \mathrm{C}$ under alternating light and dark regimes for 10 days. After incubation fungal growth colonies were observed. Spores and acervuli were observed under microscope which showed presence of falcate shaped conidia of Colletotrichum capsici.

Preparation of spore suspension: After 14 days, conidia were gently scraped from the colony surface into the petriplates, with a sterile loop and diluted it in sterile distilled water under aseptic condition. The spore suspension was then filtered through cheesecloth. Desired quantitirs of spore suspensions were made with the help of haemocytometer and spore suspension dilution technique.
Plant material: Healthy cowpea seedlings of 5 days old were placed in pots filled with soil where some pots kept for treated (seedlings were sprayed with spore suspension) and some pots kept for control (seedlings were sprayed with sterile distilled water).

Effect of inoculation of spore suspension on cowpea seedlings: Spore suspensions of $1 \times 10^{7}$ conidia per milliliter concentration were made by spore dilution technique. Spore suspension was sprayed over the cowpea seedlings selected for test and covered with perforated transparent polythene sheets for uninterrupted biological and physiological activities. Experiment sets were kept under observation regularly for a week. For control sets, only distilled water was sprayed.

\section{Results and Discussion}

Collection and identification of isolates: Isolates of Colletotrichum spp. were obtained from infected chilli fruits showing symptoms of anthracnose identified by based on the morphological descriptions of Colletotrichum species outlined by Mordue (1967) and Sutton (1992).

Culture colony characteristics: Depending upon colony growth after 7 days following subculturing on PDA were observed white to grey; most of the isolates showed the concentric zonation of dense and sparse development of aerial mycelium, sometimes with beige-coloured pin point spore masses.

Conidial morphology: Under microscope spores have been observed. Large falcate conidia have been observed with both ends tapering with the presence of centrally located nucleus.

Appressorial morphology: Appressoria showed irregular shaped in slide culture under the microscope with the presence of stiff dark seta and conidia.

Pathogenicity testing and further results of necrotrophy: Inoculation with spore suspension on cowpea seedlings after 7 days (DAI) showed severe infection of disease with water soaked lesions with prominent black acervuli all over hypocotyls. Infected seedlings showed weak growth and some seedlings deteriorated soon. After which no more growth (only grew for 3 inches) were observed among those alive seedlings and were soon wilted and destroyed. This is the characeristic symptoms of anthracnose showing hemibiotrophy of the causal organism $C$. capsici by development of necrotrophy (death of the plant by the fungus). Whereas for control sets, seedlings flourished with normal healthy growth.

Cross section of infected seedling shows presence of conidia and mycellia. In cortical area cells are distorted due to stress for the presence of pathogen. Epidermal cells also are distorted and shows dark layer due to infection. 


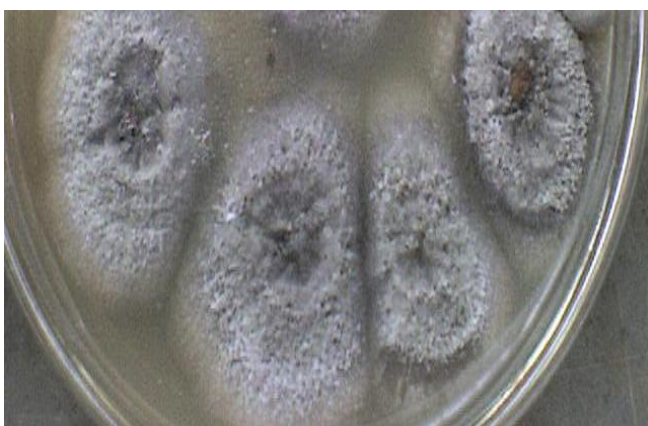

Figure A: Colonies of Colletotrichum capsici (isolated 1 lant parts in PDA)

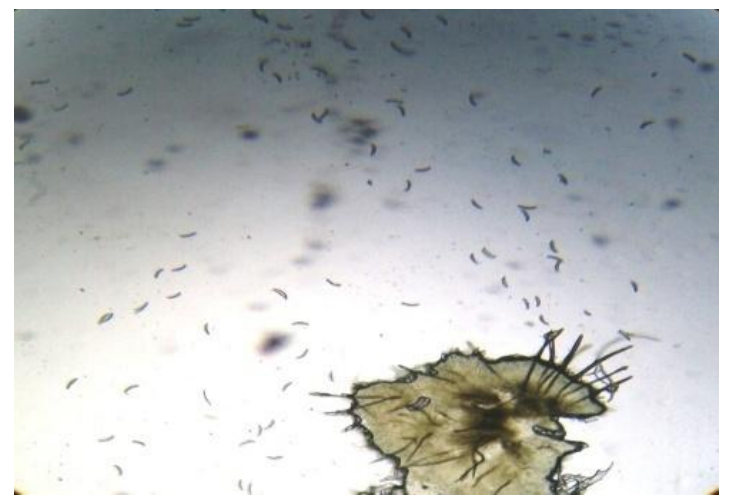

Figure B: Conidia of $C$. capsici (45x magnification) ur der compound microscope

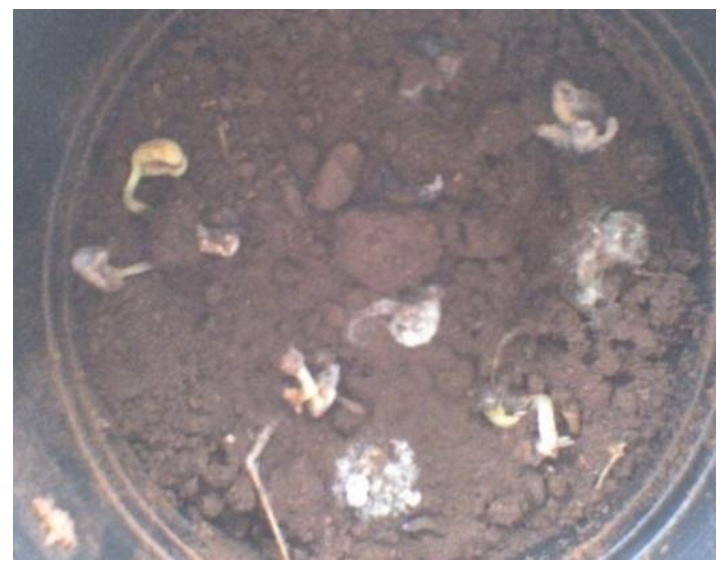

Figure C: Infected cowpea seedlings 7 DAI (DAI= Days after inoculation)

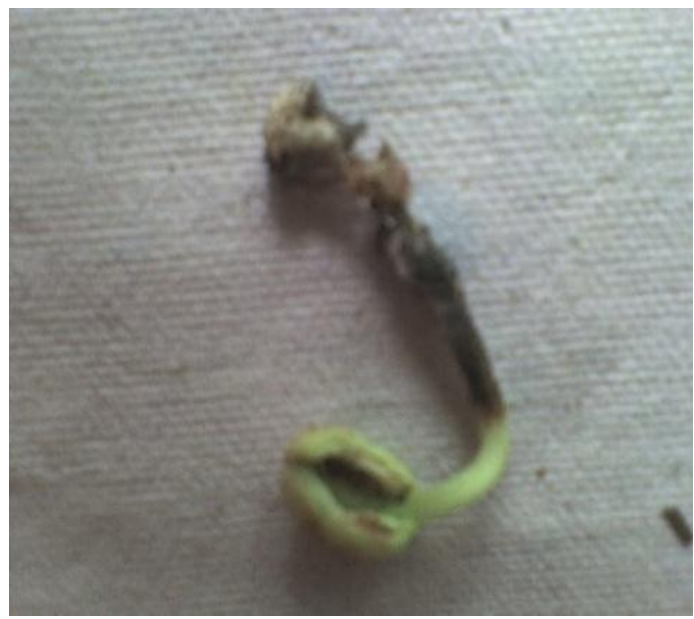

Figure D: Anthracnose affected seedling (DAI= Days after inoculation)

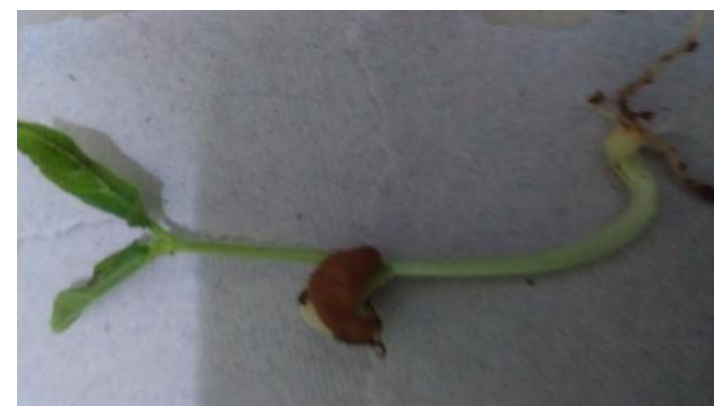

Figure E: Healthy cowpea seedling

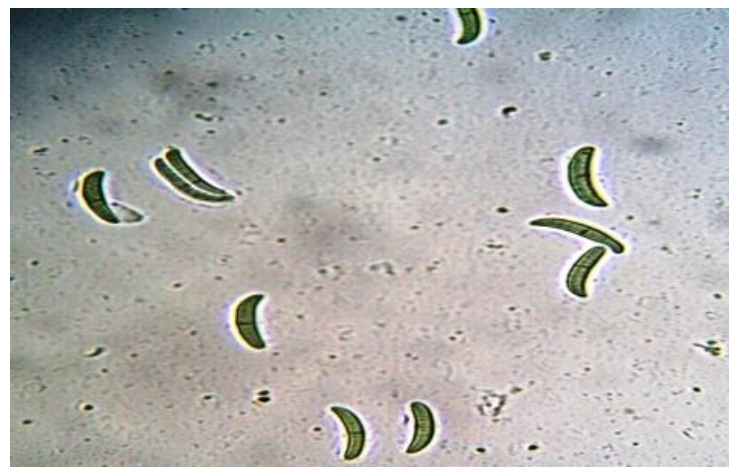

Figure F: Enlarge view of conidia

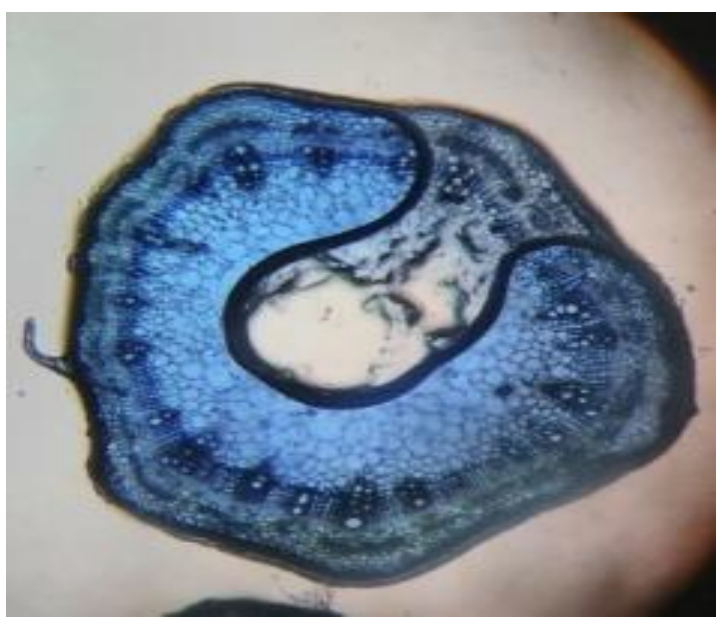

Figure G: Infected stem in cross section

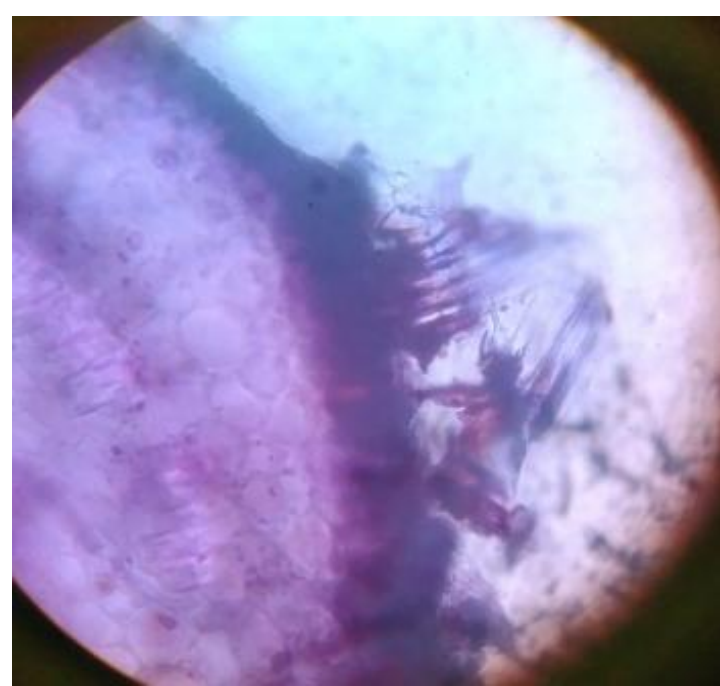

Figure H: Distorted epidermis (T.S.)

Volume 4 Issue 11, November 2015 www.ijsr.net 


\section{International Journal of Science and Research (IJSR) \\ ISSN (Online): 2319-7064}

Index Copernicus Value (2013): 6.14 | Impact Factor (2014): 5.611

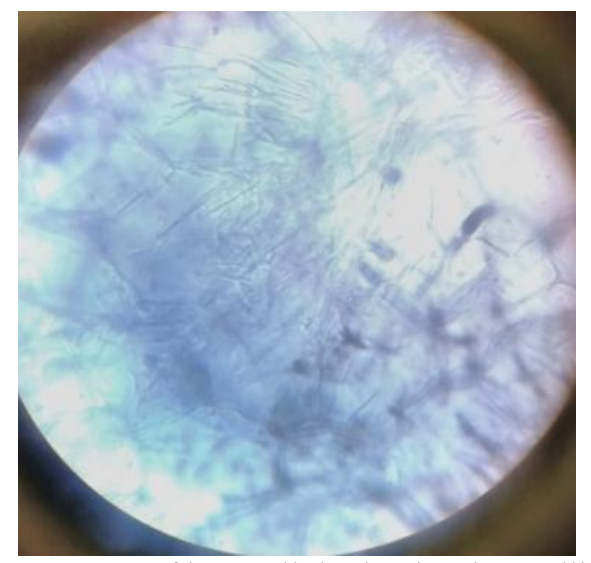

Figure I: Presence of intracellular hyphae in seedling (T.S.)

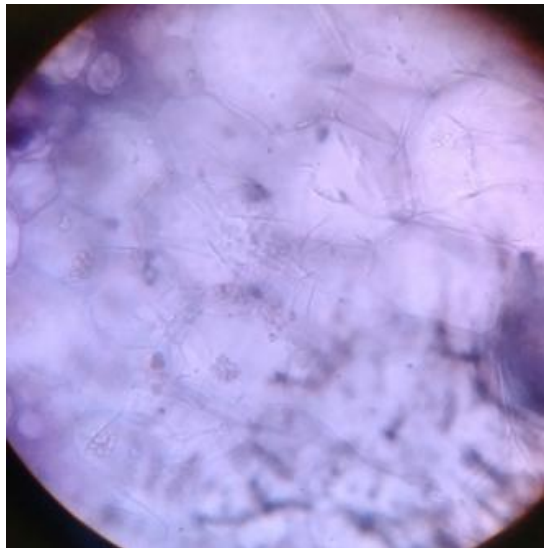

Figure J: Distorted cortex of infected cortical cells

C. capsici is the causal agent of chilli anthracnose and causes major loss to Capsicum spp.. In this study, it has been further observed that it can affect other host too other than chilli family i.e. cowpea (leguminous) and causes death of seedlings. This is in line with the studies conducted by Pring et al, 1995.

In this experiment it has been observed that in the early stages of plant development, if the host infected severely by $C$. capsici then further physiological process and development shuts down and death of seedling is inevitable. This is a characteristic necrotrophic nature of Colletotrichum $s p$. which is proven clearly that its infection is fatal for other plants also other than chilli by producing large intracellular hyphae within the cells of susceptible host. It supports the fact that Colletotrichum can affect multiple hosts (Ajay Kumar Gautam, 2013).

In several studies mode of infection of Colletotrichum spp. have been described clearly. Studies showed that for postpenetration infection of $C$. gloeosporoides (and ( : : : members of the $C$. orbiculare species aggregate) $C$. sublineolum and $C$. graminicola, comprise a small sphe ical vesicle attached to large, specialized primary hyphae $\mathrm{w}$ hich are capable of sustaining a sequential biotrophic moc $\approx$ of infection extending beyond the initially penetrated host cell (Bailey et al., 1992; Wharton \& Julian, 1996; Perfect $e$ al.. 1999). But in this study it has been observed that infection by $C$. capsici on host surface begins with the formation of appressoria then production of infection hyphae.
This experiment leads to an idea that whether $C$. capsici can be used as mycoherbicide in killing weeds in crop growing fields since very less attention has been given on its hemibiotrophy nature and its use, as Cartwright (1992) showed in his experiment on morning glory. Using this deteriorative nature of $C$. capsici Cartright et al, evaluated it as mycoherbicide on pitted morning glory (Ipomoea lacunosa), after proving its pathogenecity on the weed. In laboratory and growth chamber tests proved that $C$. capsici as a potential mycoherbicide on pitted morning glory.

\section{Conclusion}

The study findings and literature survey has showcased infection by $C$. capsici to host plant cowpea is non host specific and infection in seedlings proved fatal (necrotrophy) at the end of the infection process. This property can be used in other useful terms for killing unwanted weeds by using it as mycoherbicides.

\section{References}

[1] J.A. Bailey, C. Nash, R.J. O’Connell, R. A. Skipp. Infection process and host specificity of a Colletotrichum species causing anthracnose disease of cowpea, Vigna unguiculata. Mycol Res. 94, 810-814. 1990.

[2] Bailey J, O'Connell R. J. Plant cell death: a determinant of disease resistance and susceptibility. In: Graniti A, Durbin RD, Ballio A (eds) Phytotoxins and plant pathogenesis NATO ASI Series, Vol H27. Springer, Berlin, Heidelberg, New York, Tokyo, pp 275-283. 1989.

[3] C.D Boyette, D. Gealyb, R.E. Hoaglandc, K.C. Vaughnc and A. J. Bowling. Hemp sesbania (Sesbania exaltata) control in rice (Oryza sativa) withthe bioherbicidal fungus Colletotrichum gloeosporioides $\mathrm{f}$. sp. aeschynomene formulated in an invert emulsion. Biocontrol Science and Technology, Vol. 21, No. 12, 13991407 December,2011.

[4] E.J. Butler Fungi and Disease in Plants. Thacker Spink and Co. Calcutta, India. 1918

[5] D.K. Cartright, and G.E. Templeton. Preliminary assessment of Colletotrichum capsici as a potential mycoherbicide for control of pitted morningglory. Plant Dis. 76:995-998. 1992.

[6] R.F. Cerkauskas Latent colonization by Colletotrichum spp.: epidemiological considerations and implications for mycoherbicides. Can J Plant Pathol. 10: 297-310. 1988

[7] M.D. Coffey and U.E. Wilson. Histology and cytology of infection and disease caused by Phytophthora. In: Erwin DC, Bartnicki-Garcia S, Tsao PH (eds) Phytophthora - its biology, taxonomy, ecology and pathology. The American Phytopathological Society, St. Paul, p 289-301. 1983.

[8] R. Dean, J.A.L. Van Kan, Z.A. Pretorius, K.E. Hammond-Kosack, A. Di Pietro. The Top 10 fungal pathogens in molecular plant pathology. Molecular Plant Pathology 13: 414-430. 2012. [PubMed] 


\section{International Journal of Science and Research (IJSR) \\ ISSN (Online): 2319-7064}

Index Copernicus Value (2013): 6.14 | Impact Factor (2014): 5.611

[9] K.Gautam, The genera Colletotrichum: an incitant of numerous new plant diseases in India. Journal on New Biological Reports: 3(1): 09 - 21 ISSN 2319 -1104 (online) 2014.

[10] K.K. Kim, J.B. Yoon, H.G. Park, E.W. Park, Y.H. Kim. Structural modifications and programmed cell death of chilli pepper fruits related to resistance responses to Colletotrichum gloeosporioides infection. Genetics and Resistance. 94:1295-1304. [PubMed] 2004.

[11]A.O. Latunde-Dada and J.A. Lucas. Localized hemibiotrophy in Colletotrichum: cytological and molecular taxonomic similarities among $C$. destructivum, C. linicola and $C$. truncatum Article first published online: 12 MAR 2007 DOI: 10.1111/j.13653059.2007.01576. Plant Pathology, Volume 56, Issue 3, pages 437-447, June 2007.

[12]D.H. Lewis. Concepts in fungal nutrition and the origin of biotrophy. Biol Rev. 48:261-278. 1973.

[13]E.S. Luttrell. Parasitism of fungi on vascular plants. Mycologia.. 66: 1-15. 1974

[14] K.S. McLean \& K.W. Roy. Weeds as a source of Colletotrichum capsici causing anthracnose on tomato fruit and cotton seedlings. Canadian Journal of Plant Pathology. Volume 13, Issue 2, pages 131-134. 1991.

[15]D.L. Mason Host-parasite relations in the Gibberidea disease of Helianthus strumosus. Mycologia . 65: 11581170. 1973.

[16]J.E.M. Mordue. Colletotrichum coccodes. CMI Description of Pathogenic Fungi and Bacteria 131. 1967.

[17] S. Münch, U. Lingner, D.S. Floss, N. Ludwig, N. Sauer, H.B. Deising, The hemibiotrophic lifestyle of Colletotrichum species. Journal of Plant Physiology 165. 41-51. 2008.

[18]R.J. O'Connell. Absence of a specialized interface between intracellular hyphae of Colletotrichum lindemuthianum and cells of Phaseolus vulgaris. New Phytol. 107: 725-734. 1987.

[19] Panday, B.K. Pandey, M. Muthukumar L.P. Yadava, U.K. Chauhan. Histopathological study of infection process of Colletotrichum gleoesporioides Penz. And Sacc.on Mangifera indica.Plant Pathology Journal. 11(1): 18-24, 2012.

[20]A.K. Pandey, R.S. Luka, S.K. Hasija, R.C. Rajak. Pathogenicity of some Fungi to Parthenium, an Obnoxious Weed in Madhya Pradesh. Journal of Biological Control,.volume 5, issue 2. 1991.

[21] R.J. Pring, , C. Nash, M. Zakaria, J.A. Bailey. Infection process and host range of Colletotrichum capsici. Physiological \& Molecular Plant Pathology. 46(2): 137-152. 1995.

[22] R.K. Salar, S.K. Gahlawat, P. Siwach and J.S. Duhan. Biotechnology: Prospects and Applications, ISBN: 97881-322-1682-7 (Print) 978-81-322-1683-4 (Online)

[23] B.B. Singh, D.R. Mohanraj, K. E. Dashiell and L.E.N. Jackai. Edited. Advances in Cowpea Research. 1997.

[24]B.C. Sutton,. The genus Glomerella and its anamorph Colletotrichum. In: Colletotrichum Biology, Pathology and Control (eds. J.A. Bailey and M.J. Jeger). CAB International, Wallingford, UK: 1-26. 1992.

[25] P.P. Than, R. Jeewon, K.D. Hyde, S. Pongsupasamit, O. Mongkolporn and P.W.J. Taylor,. Characterization and pathogenicity of Colletotrichum species associated with anthracnose on chilli (Capsicum spp) in Thailand. Plant Pathology. 57: 562-572. 2008.

[26]C.B. Yandco-Ables, , E.N. Rosskopf and R. Charudattan. Plant Pathogens at Work. Progress and Possibilities for Weed Biocontrol Part 2: Improving Weed Control Efficiency. Online. APSnet Features. 2006.. doi: 10.1094/APSnetFeature-2006-0906

\section{Authors Profile}

Dr. C. Maya, is an Associate Professor in Deptt. of Botany in Bangalore University, Bangalore, Karnataka holding degrees of $\mathrm{M}$. $\mathrm{Sc}, \mathrm{M}$. Phil and Ph. D. She is a mentor of many Research Scholars.

Ms. Nabamita Seal, is a research scholar and pursuing doctorate degree from Bangalore University in Deptt.of Botany, under the guidance of Dr. Maya. 